\title{
Controle de Armamentos e Poder Militar
}

\author{
John Kenneth Galbraith
}

Devo falar-lhes do meu prazer de estar aqui, neste belo e nada acanhado campus, esta manhã. Devo também dizer-lhes que estou no Brasil há uma semana e falar-lhes da minha satisfação em tirar umas férias da economia. É a primeira vez que tenho a oportunidade de abrir a boca sem que me peçam imediatamente que dê minha opinião sobre o Plano Cruzado II. Compareci a uma série de entrevistas coletivas de imprensa, nas quais os jornalistas fizeram todos sempre a mesma pergunta. Foi um sacrifício assegurar-me de lhes dar sempre a mesma resposta.

Estou aqui, esta manhã, a convite do Goldemberg. É um convite que se originou do interesse comum que partilhamos e da identificação que ambos temos com uma organização que vem sendo altemadamente chamada de "Parlamentares para a Ação Global" ou "Iniciativa de $\mathrm{Paz}$ dos Cinco Continentes". Vimo-nos pela última vez em um Encontro no México, onde comungamos nossa preocupação com aquele que é o maior problema da atualidade: descobrir como podemos garantir a continuidade da sobrevivência do Planeta e a continuidade da sobrevivência civilizada das pessoas que habitam este mundo. É em relação a tal tema que desejo fazer meus comentários iniciais.

A inquietação central, à qual me refiro nesta ocasião, relaciona-se a um fator que exerce decisiva infuência de controle sobre os orçamentos, a dívida, a privação e a fome existentes no nosso tempo, e que também se relaciona à questão crucial da nossa sobrevivência. A origem desta questão é algo que me tem preocupado de forma crescente, nos últimos tempos.

\section{O Poder Militar}

Creio que, se quisermos avaliar a nuvem sob a qual vivemos, o perigo reinante da nossa época, precisaremos começar a redefinir de maneira mais precisa $o$ poder ao qual estamos sujeitos neste mundo como indivíduos - como pessoas. Creio que, quando fizermos isso, daremos maior atenção ao que hoje chamarei (sem qualquer pretensão inovadora) de poder militar da nossa era. Daremos atenção ao papel que o poder militar exerce em nações grandes, pequenas e médias, à forma pela qual a crescente militarização hoje ameaça a sobrevivência de todos no Planeta e à maneira pela qual a militarização, através da simples privação e da fome, é efetivamente uma ameaça à vida de muitas pessoas - muitos milhões de pessoas - no presente imediato. Esta manhã, quero falar-lhes sobre a natureza deste poder.

Quando me refiro ao poder militar, refiro-me, é claro, às Forças Armadas de qualquer país: ao Exército, Marinha e Aeronáutica. Mas também me refiro à burocracia civil que a eles está associada, que dirige e presta serviços ao poder militar. Também me refiro ao complexo industrial a serviço dos militares.

Refiro-me igualmente a um assunto algo técnico e um tanto delicado de ser tratado em uma universidade, que é o do papel dos cientistas e engenheiros empregados sob os auspícios do poder militar. Não é preciso dizer que me refiro, da mesma forma, aos políticos que se tornam cativos do poder militar e por ele são controlados. De maneira geral, faço referência àquilo que o presidente Dwight D. Eisenhower chamou, no seu discurso mais notável (e alguns diriam que foi seu único 
discurso notável), de "conflitos industriais militares". Refiro-me também à organização que, em contrapartida, existe na União Soviética, e aos organismos, um pouco menos abrangentes, que há em outros países. Tudo isso é o que chamarei de poder militar, esta manhá.

No tocante às duas grande potências, a posição é mais do que clara, se nos detivermos para observá-la. As duas superpotências, como ainda são chamadas, atualmente exibem armamentos de uma força destrutiva inimaginável. E procuram incessantemente obter ainda mais armas, armamentos de poder desestabilizante cada vez maior, sistemas de controle por computador cada vez mais perigosos e cada vez mais fáceis de serem detonados. Desejam tambem armas de custo cada vez maior.

Acredito, contudo, que nesse particular cometemos um erro quando culpamos os governos - o governo dos Estados Unidos ou o governo da União Soviética. É preciso enxergar mais a fundo, olhar para além dos governos onde reside a influência à qual os próprios governos estão sujeitos, hoje em dia. Isto é algo que fazemos em pensamento mas que, de forma geral, evitamos fazer por escrito ou verbalmente. Existe, em muitas partes do mundo, sem excluir os Estados

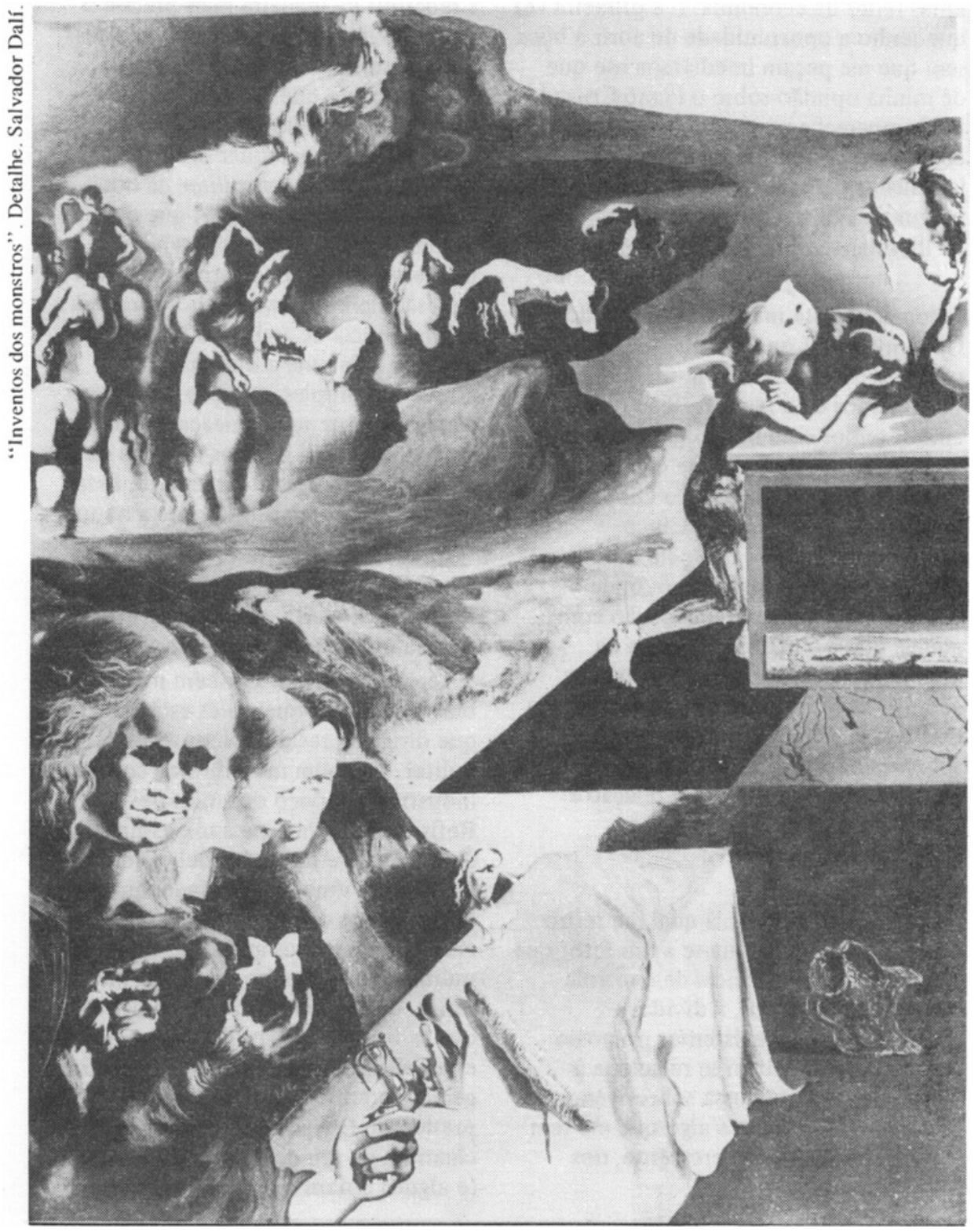


Unidos e a União Soviética, uma espécie de temor que toma conta das pessoas quando se trata de falar sobre o poder militar. O máximo em termos de poder é ser tão poderoso a ponto de as pessoas ñ̃o quererem falar sobre o poder que se exerce.

Esse poder mais amplo, mais profundo, é que atualmente influencia $e$ talvez até controle a política governamental. É um poder que se desenvolve (este é um ponto extraordinariamente importante) através de uma relação de estreita cooperação entre o poder militar soviético e o poder militar americano, no caso das duas superpotências. Existe uma dinâmica de interação a serviço do poder militar de cada país. Cada um dos efetivos militares realiza uma ação que exige, em contrapartida, uma reação correspondente no outro país. A seguir dá-se o contrário. Cada um dos estabelecimentos militares sente-se obrigado a realizar determinada ação porque isso e o que o outro está fazendo, ou pretende fazer ou poderia fazer. Desta forma, o poder militar de um país ajuda a sustentar a autoridade do poder militar no outro, numa relação cooperativa crescente até a catástrofe eventual.

\section{A Questão Armamentista}

Falamos com frequiência, nos Estados Unidos, sobre a necessidade de existir maior cooperação entre os Estados Unidos e a URSS - a União Soviética. Mas já existe uma cooperação militar em nível altamente desenvolvido. No ano de 1958, o primeiro-ministro Kruschev foi aos Estados Unidos e manteve longas conversações com o presidente Eisenhower. Numa dessas conversas, Eisenhower disse: 'Nós somos um país rico, mas eu estou sempre sendo pressionado pelos meus generais, para que lhes dê mais armas. Eles dizem que isso é necessário por causa do que vocês estão fazendo. Procuro resistir às pressōes mas, por fim, acabo cedendo. Isso acontece no seu pais?". Kruschev respondeu: "No nosso pai's é diferente. Os generais também vêm me dizer que precisam de mais armas mas eu lhes respondo: Camaradas, estamos construindo o socialismo neste pats e nāo temos recursos para isso'. Entâo eles me afirmam que, nesse caso, não podem garantir a proteção da Nação contra os Estados Unidos. A partir dai, presidente Eisenhower, nossa situação é semelhante. Eu também acabo concordando em dar-lhes armas".

As conseqüências de tudo isso são bem claras. Essa relação, repito mais uma vez, representa uma ameaça para toda a humanidade e para toda a vida do Planeta. Seria desnecessário dizê-lo diante de uma plateia universitária como esta. Trata-se de um assunto do qual vocês ja estão suficientemente cientes. Mas, além disso, há também o desvio de recursos que esta competição acarreta, recursos estes que poderiam ser utilizados para o bem estar. No meu país, os Estados Unidos, as evidencias disso são bem claras, estão ali aos olhos de quem quiser vê-las.

O Japão e a Alemanha, após a Segunda Guerra Mundial, tomaram-se as duas grandes histórias de sucesso economico dos últimos quarenta anos. A sorte para a economia desses dois países foi terem perdido a Guerra pois, em conseqüência disso, voltaram-se para conquistas civis, não militares. Foram obrigados pelos vencedores a limitar seus gastos militares e a canalizar as energias para o êxito civil. Desta forma, houve capital disponivel para a indústria civil. Foram utilizados recursos de capital, os quais, nos Estados Unidos (e também na Inglaterra), eram destinados a armamentos.

Em 1979, para falar de uma época anterior ainda d̀ recente corrida armamentista, a relação entre gastos militares e capital civil, nos Estados Unidos, era de 33. Essa era a proporção daquilo que gastávamos para fins militares quando comparado ao que gastávamos com a criação de capital civil. Na Alemanha, por outro lado, a proporção dos gastos militares versus formação de capital civil era de apenas 20 e no Japão de 3,7. Além disso, ao desenvolver sua indústria civil, os japoneses contavam com o talento para a ciência e para a engenharia, talento esse que nós dedicamos a estéreis objetivos militares.

$O$ sucesso industrial japones - o milagre econômico do nosso tempo - é 
conseqüência direta e inevitável dos pequenos recursos econômicos destinados a fins militares e da escassez de capital e de força de trabalho dedicadas a isso. Seria conveniente notar que este fato (o dos motivos do êxito japonês) é algo que nossos porta-vozes, nos Estados Unidos, percebem de forma implícita, pois agora começam a incentivar o Japão a gastar mais com a ampliação de seus efe tivos militares. A lógica por trás disso, evidentemente, é a de que assim a indústria civil japonesa seria prejudicada.

Vou desviar-me do assunto para lembrar um fato que ocorreu há muitos anos atrás. Eu estava depondo sobre esses assuntos diante do Congresso dos Estados Unidos e do chefe da comissão, o senador William J. Fullbright, um dos grandes parlamentares do mundo de língua inglesa. Quando terminei minha exposição, ele disse: "Os alemães e os japoneses obtiveram exito porque perderam a Guerrá e porque nós impusemos limites aos gastos militares que eles realizavam": Concordei com isso e Fullbright continuou: "(...) Agora estamos chegando ao fim dessa guerra com o Vietnã ". "Espero que sim", respondi. " $E$ nós não estamos ganhando essa guerra, estamos?", ele indagou. "Não, não estamos", disse-lhe. "Será que não haveria um jeito de fazer com que o inimigo de Hanó limitasse de forma parecida os nossos gastos militares?" Tive que dizer-lhe que a sugestão dele não era muito prática.

\section{Desenvolvimento e "Armamentismo"}

Não falo com a mesma autoridade sobre os efeitos do desvio de recursos financeiros para armas e usos militares quando me refiro à economia soviética. $\mathrm{O}$ esforço militar é, por natureza, um exercício de economia planejada, um objetivo econômico planejado. Talvez,

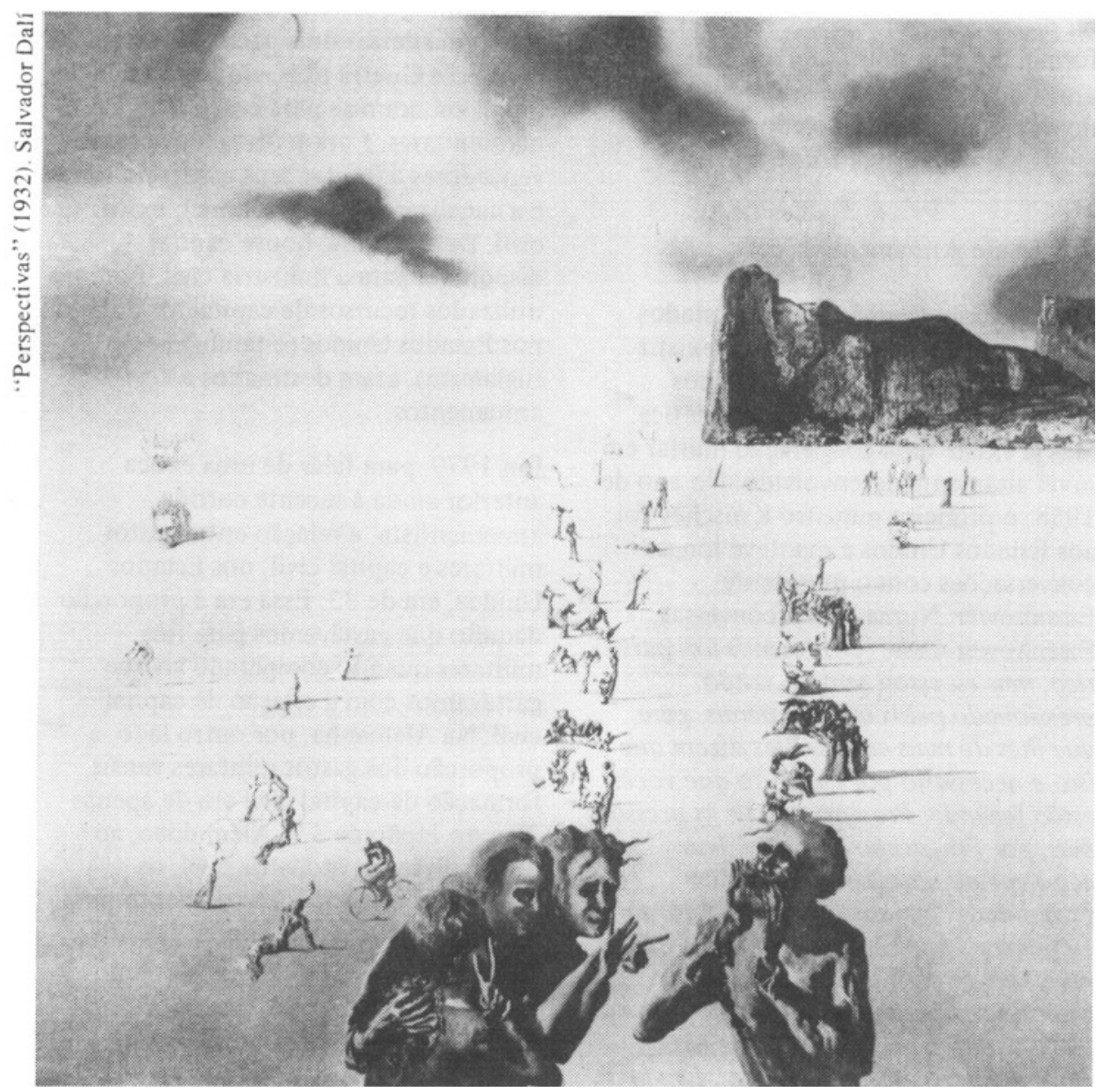


numa economia onde o planejamento é a norma ou é pelo menos habitual, os gastos militares sejam menos nocivos do que são no nosso mundo menos controlado, menos dirigido. Estou absolutamente convicto de que os meus compatriotas que apregoam que através de maiores gastos militares conseguiremos fazer com que os russos retrocedam, completamente convencido de que aqueles que dizem que aumentando os gastos levaremos os russos à submissão são (sem querer abrandar a expressão nem mesmo neste agradável ambiente académico) malucos. Apesar de tudo, não se pode duvidar de que o socialismo tem em comum com o capitalismo os mesmos efeitos nefandos do uso de recursos para fins militares. Podemos afirmar com segurança que a malefica concorrência entre os estabelecimentos militares das duas superpotências e a exigência que ela faz sobre os recursos econômicos é amplamente prejudicial para ambos. $E$ assim que atua o poder militar entre as grandes potências (como ainda são chamadas, repito) e no interior de cada uma delas.

Os bispos católicos da França, falando com a sucinta precisão que se espera dos franceses, colocaram muito bem a questão ao povo. Eles disseram: "Todo cidadão paga o preço das armas nucleares. Primeiro com impostos e depois como vitima em potencial".

Existem muitos países onde os dirigentes civis (como nas Filipinas de hoje) vivem olhando temerosamente por cima do ombro para ver o que os generais e os coronéis estão se preparando para fazer. Esta é uma das formas de opressão: a tomada direta do poder, a efetiva supressão da democracia e de suas promessas. Mas a opressão mais ampla, mais profunda, deriva dos enormes e horripilantes custos da organização militar nos paises pobres.
Mas não é somente (nem talvez de maneira especial) nos grandes paises industrializados que devemos reagir contra o poder militar e sua causa. Este é um gravame que também oprime os países pobres do Planeta. Uso a expressão paises pobres para fugir do eufemismo. É notável verificar o quanto se evitou usar essa frase, essa referência. Houve uma época em que falávamos de paises subdesenvolvidos, mas isso não parecia ser muito correto. Então passamos a falar em paises em desenvolvimento mas, no caso de alguns países, tinha-se a impressão de que a denominação era um pouco otimista demais. A seguir falamos em Terceiro Mundo, apesar de nunca ter ficado claro qual era o segundo mundo, afinal. Depois passamos a referir-nos a Norte e Sul. Penso que aqui, neste encontro acadêmico realizado num dos paises industriais em maturação, posso tranqüilamente referir-me a paises pobres. $O$ ônus militar também está representado no gravame que ele impóe a esses países. Isto ocorre de duas maneiras. Em cerca da metade das nações do mundo, o poder militar exerce seu domínio sobre o povo dire ta ou indiretamente, hoje em dia.

Um dos prazeres que sinto em vir ao Brasil, nesta ocasião, é o de estar num pais que foi recentemente libertado desse poder. Mas em outros lugares (é preciso encarar a triste realidade), em muitas partes da África e de forma extensiva em outras regiões, o povo trocou o domínio colonial do século passado pelo domínio militar deste século. E isso não é tudo. Existem muitos paises onde os dirigentes civis (como nas Filipinas de hoje) vivem olhando temerosamente por cima do ombro para ver o que os generais e os coroneis estão se preparando para fazer. Esta é uma das formas de opressão: a tomada direta do poder, a efetiva supressão da democracia e de suas promessas. Mas a opressão mais ampla, mais profunda, deriva dos enormes e horripilantes custos da organização militar nos paises pobres. Em conjunto, os paises pobres despendem em armas maior porcentagem do seu já diminuto produto interno bruto do que os ricos. No mundo de hoje, os países pobres importam armamentos em valores que beiram os 30 bilhões de dólares ao ano. Grande parte desse sofisticado equipamento tem propositos que sequer se relacionam a qualquer possivel uso em tempo de guerra. Ele se destina a alimentar a auto estima da organização militar. Não há nenhum general em todo o mundo que se sinta totalmente seguro em sua autoestima sem possuir um caça supersônico de última geração, mesmo que estes sejam absolutamente irrelevantes para os objetivos militares.

A conseqüência $\hat{e}$, como já disse, $o$ custo enorme que isto traz para os povos mais pobres do mundo. Nos Estados Unidos, na União Soviética, Inglaterra, França e outros países industrializados, os gastos com armamentos são subtraídos de um padrão de vida relativamente alto. Mas, nos paises pobres, essa despesa se faz às custas da própria vida humana. Do outro 
lado da moeda dos atuais gastos militares em países pobres temos a privação, a fome e a morte da população civil.

O secretário-geral das Nações Unidas, Javier Perez de Cuellar, fez uma afirmação relevante sobre $o$ assunto a qual repetirei aqui. Ele disse: ' $O$ comércio de armas empobrece o receptor e corrompe o fornecedor'. Completou dizendo: "Existe uma semelhança impressionante entre o comércio de armas e o comércio de drogas".

Os gastos militares são, além do mais, uma fonte recíproca de medo, desconfiança e conflito. Isto é mais grave entre os paŕses pobres do mundo do que entre os ricos. No mês de outubro próximo, data da Revolução de 1917 , irão completar-se setenta anos em que os Estados Unidos convivem em paz (uma paz de fato, mesmo que nem sempre das mais amigáveis) com a União

Soviética. Serão setenta anos de paz entre os dois paises. Excetuando-se uma prematura e incompreensível intromissão de soldados ocidentais no fim da Primeira Guerra Mundial, nesse período ninguém morreu em conseqüência de conflito armado entre as duas superpotências. $\mathrm{O}$ mesmo não acontece no Terceiro Mundo (percebo que usei o eufemismo). Conflito armado e morte são o destino reservado, hoje em dia, aos povos mais pobres do mundo.

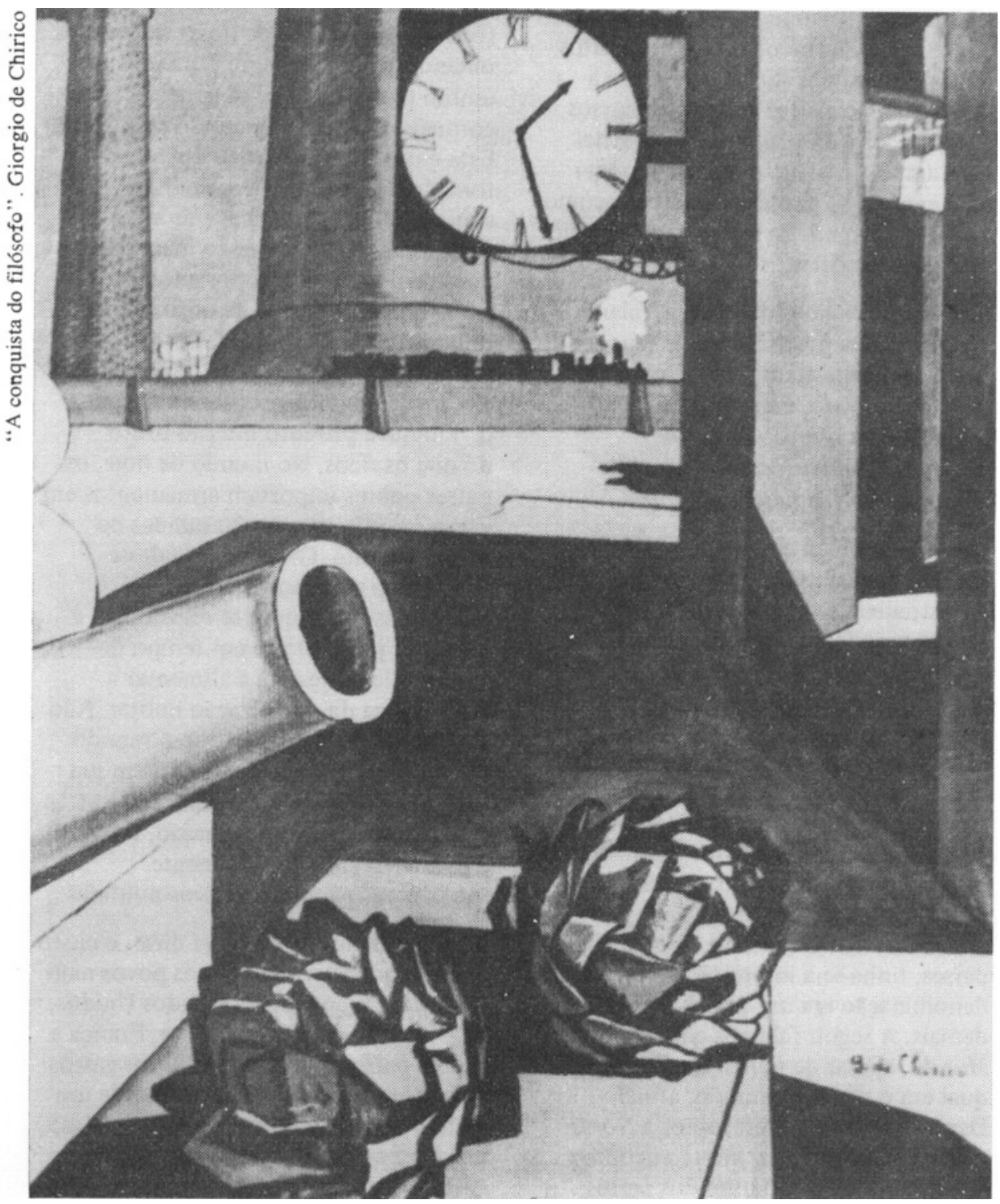


Tudo que acabo de dizer é de nosso conhecimento, tanto em relação às grandes potências quanto ds pesquenas. 0 tema, porém, não nos apaixona. De forma bastante acentuada, eliminamos o poder militar de nossas preocupações. Pensamos e falamos muito em poder. Falamos do poder das grandes corporações, do poder dos sindicatos, do poder das organizações políticas, do poder de grupos religiosos e do poder de lifderes politicamente carismáticos.

Esse poder faz parte de nossas preocupações diárias. É um assunto com o qual temos nos preocupado profundamente desde a epoca de Marx e Max Weber. Falamos bem menos do poder militar. Muito menos. E minha última pergunta, esta manhã, é por quê?

\section{Controle de Armamentos, Poder Militar e Democracia}

Não falamos nele em parte porque nossa preocupação com o poder é ultrapassada e obsoleta. Arrisco-me a dizer que é ultrapassada e obsoleta especialmente nas nossas universidades. No século passado e no começo deste, o poder das empresas capitalistas, o controle que elas exercem sobre o Estado, o poder contrário dos sindicatos e a esperança socialista de neutralização eram nossas preocupações fundamentais. E esta concepção de poder continua firmemente arraigada em nossa mente. Mas estes não são mais os conceitos social e politicamente válidos de poder. $O$ fato de não falarmos no poder militar deve-se a que nosso conceito de poder é obsoleto. Gostaria de fazer um apelo para que, no futuro, pensássemos muito mais no poder militar e muito menos na General Motors, General Electric, IBM e outras grandes companhias que talvez façam parte do poder militar, mas certamente não são mais o fator decisivo de controle. Os governos estão capacitados para saber lidar com os fabricantes de automóveis, mas estes mesmos govemos estão sujeitos à autoridade militar do complexo industrial militar.

Existem ainda outras razões para urgência. A expressão suprema do poder dá-se quando as pessoas nāo se interessam em desafiá-lo de viva voz, quando ele consegue absorver e neutralizar as reações adversas. Este e o caso do poder militar. Além disso, o poder militar tem uma aura de patriotismo e de identidade nacional. Identifica-se com nacionalismo, com patriotismo, com o Estado em si e, afinal de contas, ninguém deseja atacar seu próprio Estado. Nos lugares onde os governos são vulneraveis ou o povo é pobre e insatisfeito, ali estão os militares com suas armas. Essas armas, por mais que se tente provar o contrário, estão acima de disputas ocasionais. E o que vemos acontecer em muitos países, as Filipinas. .. Sem correr o risco de ser injustos, podemos tamberm dizer que essa não é uma situação pouco comum aqui, na America Latina. Em alguns parses (no México e espera-se que no Brasil), o poder militar foi reduzido a um papel relativamente menor. Mesmo assim, existem muitos lugares na America Latina onde, como já mencionei, os governos olham temerosos para 0 poder militar.

Devo dizer que ao chegar aqui, vindo dos Estados Unidos, surpreendi-me um pouco com as despesas militares e o serviço militar obrigatorio existentes na América Latina. Pergunto-me por que tais coisas seriam necessárias em países sem inimigos à vista. Bem, concordo que o Brasil deva ter uma grande preocupação com uma possível invasão vinda do Paraguai, mas essa é apenas uma das raras exceções. Por favor, não me levem muito a sério nessa declaração...

Chego, por fim, ao meu apelo final desta manhã. Vamos evitar as evasivas, vamos discutir o poder militar de maneira ampla, franca e aberta. Vamos falar sobre as dimensōes desse poder, sobre as formas de controlá-lo e de contrabalançar sua ação geradora de tensões internacionais tensóes estas que, obviamente, contribuem substancialmente para a manutenção do poder militar e para engordar os orçamentos a ele destinados. (E interessante notar que, nos Estados Unidos, o medo da União Soviética e de suas ações cresce consideravelmente nos dois meses anteriores à aprovação do orçamento.) Vamos discutir as formas de limitar as despesas orçamentárias militares no mundo inteiro e vamos dirigir-nos com ênfase ao comercio de armas e fazer com que ele seja refreado náo só por aqueles 
que as vendem, mas que também seja contido pelos paises que as compram. Vamos encontrar maneiras de vencer os aparelhos militares que hoje em dia controlam qualquer esforço mais significativo feito no sentido de limitar 0 armamento.

As conversações sobre limitação de armas que se desenrolam em Genebra e as que aconteceram em Reykjavik estão em grande parte sujeitas ao poder militar. Elas não se destinam, na verdade, a reduzir o poderio armamentista das superpotencias. Destinam-se a amainar o medo e a desconfiança da população e a dar a ela a impressão de que algo está sendo feito. $O$ maior perigo que existe para o poder militar é o medo que muitas pessoas sentem de morrer. É preciso, portanto, que haja dentro do poder militar algum mecanismo para suavizar esse medo. Isto e fundamental para a manutenção do poder. Por isso, as negociaçőes de controle armamentista, realizadas por um pequeno número de pessoas que costumamos chamar de teólogos nucleares, não visam d̀ efetiva redução de armas. Elas visam a reduzir o medo que as pessoas sentem da corrida nuclear, visam a arrefecer o temor popular de uma eventual extinção.

Nada disso será possível enquanto não formos capazes de reconhecer a ampla realidade da situação em que nos encontramos. Precisamos dar-nos conta de que o poder militar exerce um papel independente no nosso tempo e de que ele resiste a qualquer tentativa de limitação de sua força, limitação esta que o controle de armas, a paz mundial e a própria democracia exigem de forma urgente e politicamente inevitável.

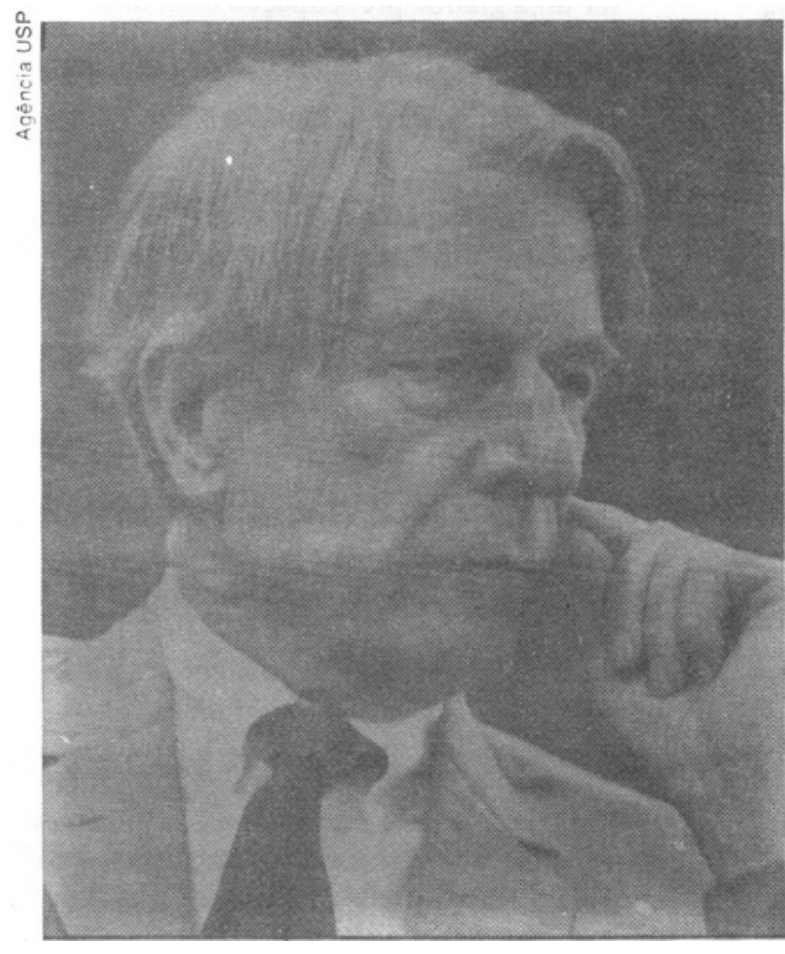

\section{John Kenneth Galbraith}

John Kenneth Galbraith, 80 , nascido no Canadá e naturalizado cidadão norte-americano, é um dos mais importantes economistas mundiais e desenvolveu intensa atividade acadêmica, sobretudo nas universidades de Cambridge, Princeton, Michigan e Harvard (EUA). Foi embaixador dos Estados Unidos na India, no governo Kennedy, de 1961 a 1963 . E autor de inúmeros artigos, coletâneas, roteiros e livros clássicos, onde podem ser destacados: A merican capitalism (1952); The great crash (1955); The affluent society (1958); The liberal hour (1960); The new industrial state (1967);Ambassador's journal (1969); China passage (1973); Economics and the public purpose (1974); Money: whence it come where it went (1975); The age of uncertainty (1977, traduzido pela Editora Pioneira sob o título $A$ era da incerteza). 